\title{
HEINONLINE
}

Citation: 19 Fed. Sent. R. 130 2006-2007

Content downloaded/printed from

HeinOnline (http://heinonline.org)

Mon Jun 25 09:44:51 2012

-- Your use of this HeinOnline PDF indicates your acceptance of HeinOnline's Terms and Conditions of the license agreement available at http://heinonline.org/HOL/License

-- The search text of this PDF is generated from uncorrected OCR text.

-- To obtain permission to use this article beyond the scope of your HeinOnline license, please use:

https://www.copyright.com/ccc/basicSearch.do?

\&operation $=$ go\&search Type $=0$

\&lastSearch $=$ simple\&all=on\&titleOrStdNo=1053-9867

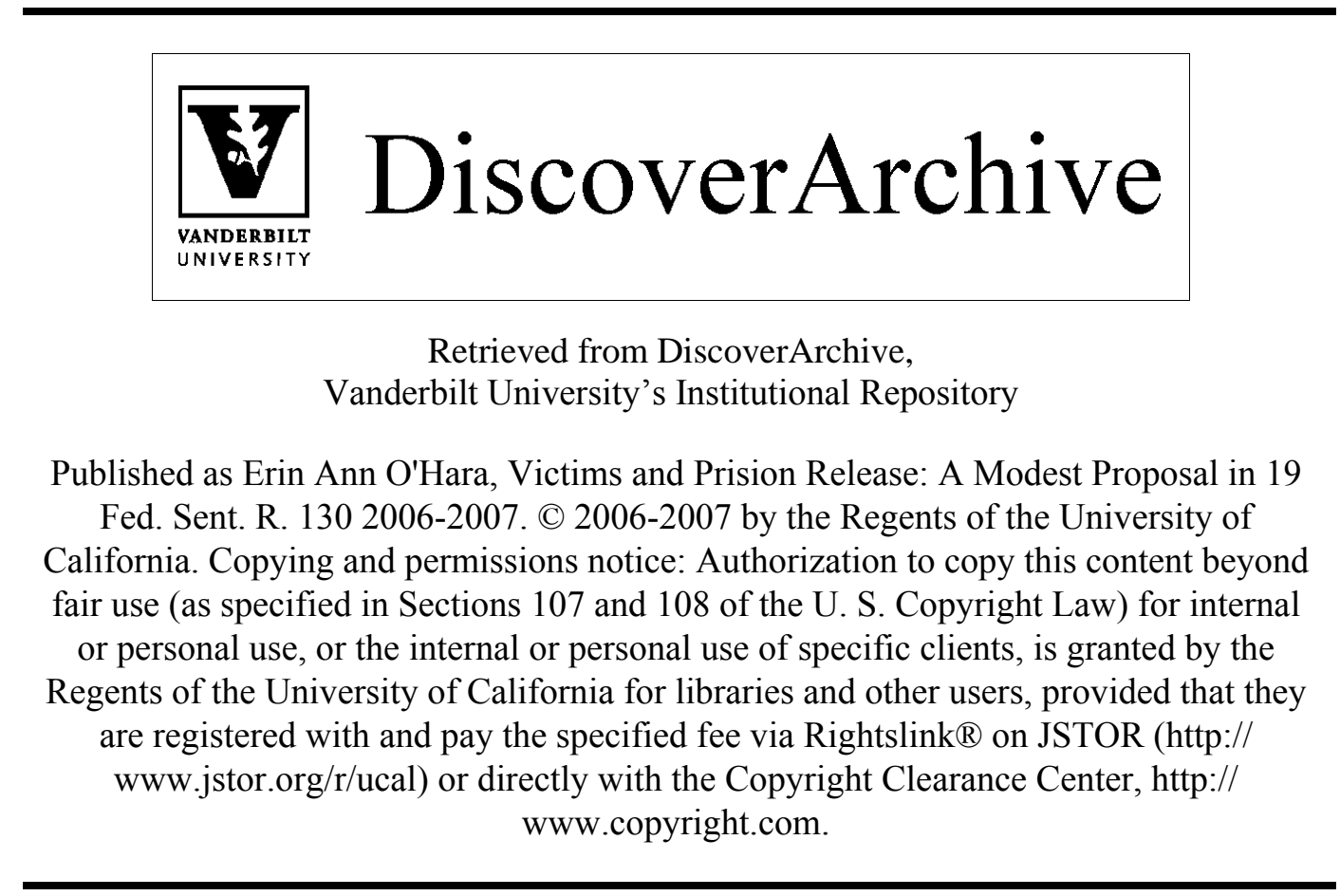




\section{Victims and Prision Release: A Modest Proposal}

Given what is contained in this Essay, I feel compelled to start with a disclaimer regarding what this Essay is not about. It is not a disguised attempt to either lengthen or shorten prison terms. It is not an attempt to thwart any of the aims of prosecutors, defense attorneys, parole officials, juries, or society at large. It is not even an attempt to change either the criminal law enforcement budget of the state or federal governments or to change the course of how those budgets are allocated.

The agenda contained in this Essay is much simpler and, therefore, perhaps hopelessly naive. This Essay proposes that governments experiment with decisions regarding release from prison by giving victims control over the imposition of the last Io percent of the convict's sentence of imprisonment. The goal is to remain agnostic about the vast majority of criminal justice debates while providing a potential benefit to crime victims. If successful, the experiment could also produce significant benefits for criminal defendants and for society.

The proposal is "modest" for two reasons. First, because it proposes to give victims control rights over criminal punishment, it will at first appear more radical than any of the victims' rights proposals that have been enacted into law in the United States. Moreover, this Essay will claim that this seemingly radical proposal should appeal to both the political left, which decries the draconian dysfunction of our criminal justice system, and the political right, which advocates that the system be even further strengthened. With tongue in cheek, then, I claim that this proposal is "modest."

At a deeper level, however, the proposal really is modest in the sense that it would cost little, is capable of gradual experimentation, and, if carefully constructed, could produce significant benefit and little or no harm. Along the way, we could retain our commitment to criminal procedural protections, prosecutorial control, and the use of crime to vindicate the interests of society. While seemingly radical, then, the proposal could be surprisingly simple and noncontroversial. To be sure, there are significant complications and potential problems that would need to be worked through. I leave that more detailed inquiry for a future article. The basic proposal and the goals it can serve are presented here.

\section{Victims' Rights}

Over the course of the history of Western civilization, the role of victim in criminal law has changed dramatically. Before the advent of state prosecutors and criminal justice systems, crime victims who sought vindication, vengeance, or justice from the courts were forced to finance their own investigations and prosecutions of criminal cases, and often victims were required to pay for the perpetrator's incarceration.' In early Western legal systems, including colonial America, victims instead resorted to vigilante justice much more often. ${ }^{2}$ Today the State investigates, prosecutes, and incarcerates criminals. State criminal prosecution and punishment helps victims by ensuring that even poor victims' harms can be vindicated. ${ }^{3}$ Public prosecution and punishment also works symbolically to show victims that their communities care that their welfare has been compromised and that they are committed to punishing those who have violated them. Moreover, the public nature of criminal law today has helped to marginalize resort to vigilante justice. When violence begets violence, especially group violence, peaceful societies are threatened. State prosecution and punishment may therefore play an essential role in maintaining security and peace.

Unfortunately, in an effort to provide these important benefits to society, our governments allowed the criminal justice pendulum to swing too far in the direction of the State. Systemically, the victim was silenced. Aside from testifying at trial (assuming that there would be one), ${ }^{4}$ victims were often excluded. Victims had no right to consult with prosecutors, no ability to recommend a sentence, and, often, no right to be present at trial. Moreover, law students trained in the criminal law were and still are taught that a crime is an offense against the State. The analysis of criminal law and procedure in law school courses pits the defendant against the State. Often the victim goes entirely undiscussed. 5 Once criminal law was redefined as treating offenses against the State rather than the victim, it seemed imperative to exclude the victim's influence as much as possible.

As it turns out, however, it simply is not a stable equilibrium to exclude victims from playing a meaningful role in the context of the criminal law. ${ }^{6}$ As much as we might

Federal Sentencing Reporter, Vol. 19, No. 2, pp. 130-135, ISSN 1053-986 6 electronic ISSN $1533-8363$ (C) 2006 Vera Institute of Justice. All rights reserved. Please direct requests for permission to photocopy or reproduce article content through the University of California Press's Rights and Permissions website, http://www.ucpressjournals.com/reprintInfo.asp. DOI: fsr.2006.19.2.130. 
prefer a world where justice is meted out by detached individuals in a sanitized courtroom, the fact is that victims--even those seething with anger and a desire for the flow of blood-will eventually regain attention and authority in criminal law. Once victims organize themselves into interest groups, the criminal laws are bound to change to accommodate their desires. As constituents, we empathize with those who suffer from crimes, and we fear for our own safety when we learn about the victimization of others. Our sympathies lie with the powerless victim, and we demand that our elected representatives do something to recognize her needs. ${ }^{7}$ Law enforcement authorities and prosecutors are quick to help organize these victims and to use their platform to advocate for larger law enforcement budgets, longer prison sentences, the death penalty, the abolition of parole, and the erosion of criminal defendants' procedural protections. ${ }^{8}$ As a result, the pendulum has begun to swing back in the direction of the demands of the victim. The challenge for policy makers is to find a mechanism for satisfying some victim demands without sacrificing the just functioning of the criminal justice system.

Most if not all of the states have engaged in criminal justice reform over the past few years. "Since 1982 , thousands of federal and State statutes governing the rights and interests of crime victims have been enacted." 9 At least thirty-three states have passed constitutional amendments that grant victims a variety of rights, including the right to confer with prosecutors and the right to be notified, to be present, and to be heard at important pretrial, trial, and posttrial proceedings. ${ }^{10}$ After attempting for several years without success to pass a federal constitutional amendment, victims' rights advocates reverted to the passage of a federal victims' rights statute. ${ }^{\text {II }}$ It, too, provides crime victims with rights to notice and attendance and a right to be heard at important proceedings. Advocates have called for more, however, including the erosion or abolition of some of defendants' procedural protections. ${ }^{\mathrm{I} 2}$ Left unresolved are the questions of whether there will be a "third wave" of victims' rights reforms and what their content might include. ${ }^{13}$

\section{Restorative Justice}

Criticism of the criminal justice system takes other forms as well. In response to the ever-increasing criminal sentences and the abject failure of the prisons to reform criminals, some have argued that we need new institutions to replace formal state punishment of crimes. Instead of incarceration, they argue, restorative justice techniques should be used that could address the needs of both offender and victim, and, in some cases, the needs of the immediate community. In the past decade or two, more than a thousand victim-offender mediation (VOM) centers have opened their doors to enable the victim and offender to meet face-to-face in the presence of a mediator to discuss the crime and its effects. ${ }^{14}$ In some cases, the VOM substitutes for the criminal justice system. Youth offenders, first-time offenders, and those who have committed low-level property offenses are the most common offenders to be offered VOM in lieu of criminal prosecution. But VOM is increasingly being used for violent offenses - even rape and murder - to supplement the formal criminal justice process. ${ }^{15}$

Restorative justice advocates are full of idealism, and their proposals have a tendency to sound downright Pollyannaish. But empirical studies indicate that VOM is surprisingly successful. One study of mediations at four dispute resolution sites in four different states found that 90 percent of victims and $9 \mathrm{I}$ percent of offenders reported being satisfied with the mediation outcome. ${ }^{16}$ Compared to those victims and offenders that proceed through the criminal justice system, those who instead opt for VOM are significantly more likely to report that their opinions were considered, the outcomes were fair and satisfactory, and the offender was held accountable. ${ }^{17}$ Moreover, preliminary evidence involving juveniles indicates that those offenders who participate in VOM are significantly less likely to recidivate than those who participate in the criminal justice process, and those who do commit subsequent crimes tend to commit lower-level offenses than those who confronted the traditional process. ${ }^{18}$

Much of VOM's success must stem from the fact that participants are typically carefully screened for potential success. Even if the sample of participants biases the studies in the direction of success, however, the growing demand for the services of VOM indicates that a not insignificant portion of the victim and offender populations have a desire to address their problems directly rather than indirectly through State prosecution. To the extent that VOM provides benefits for those participants it is designed to help, state efforts to facilitate VOM should be applauded.

\section{Apology}

VOM benefits the victim and offender in part because it provides a setting in which the offender can apologize to the victim for his wrongdoing. Most victims say that they agree to VOM in order to confront the offender, to better understand why the crime happened, and/or to obtain reparations. ${ }^{19}$ When the VOM is over, however, most victims list the receipt of an apology as one of the most meaningful aspects of the meeting. ${ }^{20}$ Recent work on apology indicates that the mere threat of formal legal processes can substantially interfere with offenders' apologies to their victims. Defendants and their lawyers fear that an apology could be used at trial as evidence of the defendant's guilt. ${ }^{21}$ And yet, in the civil context, victims often report filing suit precisely because they had not received an apology for the wrongdoing. ${ }^{22}$ In addition, both anecdotal and experimental evidence indicate that plaintiffs are much more likely to settle their suits if the defendant has sincerely apologized to the victim. ${ }^{23}$

Apology provides significant benefits to victims. Often an apology takes away the desire for revenge. ${ }^{24}$ In fact, 
some prosecutors will discourage or attempt to delay VOM until after sentencing in order to preserve the victim's sense of outrage when she delivers her victim impact statement. ${ }^{25}$ Apologies can also help to alleviate victim fear because they work to provide victims with assurance that the offender will not transgress against the victim in the future. ${ }^{26}$ If a victim can set aside her fear, anger, and bitterness, she is much better able to go on with her life. In fact, the forgiveness that apology fosters may even provide tangible health benefit to the victim. ${ }^{27}$

Apology can also provide significant benefits to offenders. All too often those who commit crimes attempt to deny or minimize the harm that they have caused. ${ }^{28}$ Once an offender acknowledges the legal and moral wrong of his deeds, the offender needs an outlet for expressing his remorse and shame. An apology prevents the offender from ever thereafter reverting to denial or minimization. An apology also helps to commit the offender to a course of good behavior in the future. ${ }^{29}$ In fact, as mentioned earlier, empirical evidence seems to demonstrate that VOM, which typically produces an apology, leads to greater recidivism reductions than does the formal criminal justice system alone. Offenders who acknowledge their wrongdoing and commit to better conduct in the future are more likely to develop the self-esteem necessary to avoid reverting to crimes in the future. No doubt there are criminals who will continue to commit crimes regardless of the dispute resolution processes that they submit to. For those who are capable of reformation, however, the apology increases the likelihood of reform.

The powerful benefits from apology have recently been acknowledged by criminal law scholars. Stephanos Bibas and Richard Bierschbach's recent article described a variety of proposals intended to encourage offenders to apologize to their victims..$^{\circ}$ In particular, they suggested that prosecutors and police officers could exercise their discretion not to arrest or prosecute low-level offenses where the offender has apologized to the victim. ${ }^{31}$ Plea hearings could be attended by victims, and judges could actively attempt to get the defendant to admit wrongdoing and to apologize to the victim..$^{32}$ Finally, the offender's apology or cooperation in VOM could be taken into account when setting the victim's sentence. 33

Each of their proposals could produce more apologies and are therefore potentially quite helpful. However, the proposals fail to address two problems that a different or supplemental focus might treat more effectively. First, most of the Bibas/Bierschbach proposals would produce apologies days, weeks, or at most months after the offense. For minor crimes, quick apologies can be very successful in that they help to dissipate feelings of revenge, frustration, and fear before these feelings have festered long enough to cause long-term damage to victims. For very serious and violent offenses, however, it could take years before either victim or offender is prepared for an apology to work effectively. 34 We would not wish to eliminate the possibility of victim-offender media- tion in these cases, however, because the benefits to victims may be even greater when the crime committed is especially harmful.

The second potential problem overlooked in the proposals is the fact that victims often benefit from feeling that they are in control of the outcome of the situation. Obviously, victims, as humans, are quite heterogeneous in their emotional reactions and needs that they experience in the aftermath of crime. Many of them, however, heal better when they are re-empowered to control at least a piece of the consequences of crime. 35 To the extent that police, prosecutors, and judges exercise their discretion to treat the defendant leniently because they feel that he has shown sufficient contrition to the victim, we are allowing third parties to determine the sufficiency of the apology with little regard to the preferences of the victim. Without victim control over the consequences of VOM, we risk failing to produce all of the benefit possible.

Victim control of the criminal justice process has, justifiably, been heavily criticized by academic commentators and strenuously resisted by courts. If a victim has complete discretion to eliminate criminal proceedings, then victims who accept apology too readily end up setting loose a criminal who could continue to prey on the victim or on others. Without criminal prosecution, the community is deprived of its ability to express moral outrage at the defendant's acts. Victim control of plea agreements could significantly hamper the ability of chronically understaffed prosecutor and public defender offices to achieve as much justice as possible with limited budgets. Moreover, victim control in criminal justice proceedings could work to deprive the defendant of important constitutional protections designed to give innocent defendants every possible opportunity to avoid criminal conviction..$^{6}$

To my knowledge, however, no one has explored the extent to which victims should be given control at the end of incarceration. What if victims could decide whether the convict could receive early release or must instead serve his entire sentence? The next section explores that possibility.

\section{Release from Prison}

Here is my modest proposal: the State should set incarceration periods sufficiently high so that the community feels comfortable about the prospect that the victim might forgive a portion of that sentence. Then, the victim should be granted control over Io percent of the convict's sentence. When the convict either (I) has ro percent of his sentence remaining; or (2) has become eligible for parole, the victim should be given the option to either forgive or impose her Io percent of the punishment. At any point between sentencing and the time when the victim's rights can be exercised, the victim should be given the opportunity to opt out of the exercise of these rights. If the victim opts out or otherwise fails to come forward, then, as a matter of default, the convict should be required to serve out the remainder of the sentence until otherwise eligible for release by the State. 
For a victim who seeks control, the proposal enables her to have a direct say in the convict's fate. By enabling the victim to exercise this control, the convict would be made aware that although imprisonment is largely about serving a debt to society, a piece of his punishment is meted out to force the convict to serve a debt to the victim. This symbolic attribute of victim control can be achieved even if victims only rarely step forward to affirmatively exercise their authority.

Victims who seek revenge might well make clear that they choose to have their portion of the sentence imposed. For those who find revenge distasteful, the proposal will smack of barbarism. The whole idea of creating a State monopoly over criminal law was to cleanse our justice systems from the primitive and dangerous sentiments toward bloodlust. As indicated earlier, however, these sentiments have not disappeared from humanity just because they have been cleansed from the system. ${ }^{37}$ All too often, the criminal justice system's denial of victim taste for revenge has led victims and their allies to resort to vigilante justice and mob violence. This proposal surely will not fully eliminate community violence in the aftermath of crime, but it might satisfy the desires for revenge of a few victims. By satisfying this desire, those victims might heal sooner and some amount of physical violence might be avoided.

More important, however, victim control over the parole or other release decisions would provide a carrot to the convict to encourage him to agree to participate in VOM. Empirical studies of VOM indicate that while victims and offenders come away from VOM valuing the apology and its aftermath, they tend to report going into VOM seeking purely selfish ends. Victims seek reparations, and offenders seek to avoid imprisonment. The convict might be extremely reluctant to enter into a setting where the person he has victimized will have a chance to confront him and his moral blame will be emphasized by both the victim and the mediator. The potential for early release might help offenders to overcome their psychological barriers to entering VOM. If successful, victim fear, frustration, anger, and bitterness can be replaced by forgiveness, and that forgiveness can (but need not) manifest itself in the victim's ceding her authority to impose the last io percent of the convict's sentence.

The proposal restores the role of the victim in criminal punishment without supplanting the community's role in ascertaining guilt or expressing the importance of its norms through criminal sentences. By shifting the victim's control right to the end of the criminal sentence, VOM can be put off until victims and offenders of serious crimes are psychologically ready to participate. Also, because the victim asserts control long after conviction and sentencing, defendants' constitutional procedural protections are preserved. Under the proposal, the lion's share of the criminal sentence will be mandatorily imposed by the community. By delegating the bulk of the revenge function to the community, the sentence imposed by the court or jury can symbolically serve to restore the victim's moral stature in the community. Moreover, by giving victims control over only a small percentage of the sentence, the community need not fear that overforgiving victims will compromise public safety. Both victims who seek revenge and victims who seek closure and forgiveness could benefit from the proposal. Victims who wish to avoid any further participation in the offender's case can sign away any right to participate in the offender's later release decision.

\section{Complications}

Although the proposal could serve several important goals, it is admittedly fraught with complications that would need to be thought through. First, the proposal will create difficulties in cases that lack a single identifiable victim. Not all crimes have identifiable victims, and some crimes involve multiple victims. In homicide cases, the victim's family typically represents the victim, but often family members have very different preferences for revenge and forgiveness. For so-called victimless crimes, this proposal would obviously not work and so should not be implemented. Where there are multiple victims, the State could either choose to allow each victim control over Io percent of the counts that pertain to her personal victimization or decide that victim control is simply unworkable in this context. In homicide cases, courts are already forced to grapple with which family members count as the "victim" for purposes of notification, consultation, and participation rights. Presumably those definitions of "victim" also could be used in the context of release control rights.

Other complications present greater difficulties and thus will be left for a full-length article. A few should at least be mentioned here, however. To be effective, this proposal must provide protections for victims who worry that they will be further victimized if they seek to exercise their rights to impose sentences. If convicts can place pressure on victims through intimidation and threats to give up their rights to impose their portion of the sentence, then victims end up being revictimized as a consequence of this proposal. To protect victims, then, parole proceedings (in jurisdictions where they still exist) ${ }^{38}$ must enable completely confidential victim participation. Whether or not a jurisdiction has retained parole, victims can only be protected if defendants are given no information about whether the victim affirmatively chose to exercise her rights to impose her portion of the criminal sentence.

Even if confidentiality could work to protect the victim, that confidentiality could arguably interfere with the convict's constitutionally protected interests in liberty. The state and federal courts seem to disagree on the extent to which this is the case, ${ }^{39}$ so as a purely pragmatic matter, this proposal might work better in some jurisdictions than in others. Finally, by using a portion of the sentence to facilitate apology, certainly guilty convicts might obtain early release from prison whereas innocent convicts (who have 
nothing to apologize for) must serve their entire sentence. This latter problem already infects both sentencing and parole decisions and, presumably, must be addressed at the charging, plea, and trial stages.

It might be that even if procedural mechanisms can take care of each of these concerns, victims will be uninterested in exercising their authority over the convict's sentence. That information could be very useful to know, however, as victims' rights groups might turn out to be wrong in their claims that victims resent being sidelined. If victims do not seek involvement in the imposition of the criminal sentence, then the default rule that the convict serves his entire sentence kicks in and we end up with essentially the same system that currently exists. If victims do seek control over the sentence and if both parties would benefit from VOM in the context of more serious crimes, then the proposal seems worth an experiment.

\section{Conclusion}

The political right pushes for the strengthening of our criminal justice system by expanding victims' rights at the expense of defendant protections. The political left advocates the gradual replacement of the criminal justice system with restorative justice techniques. At the heart of both sets of proposals is a crime victim alienated by a system that has slowly eliminated her role in criminal prosecution and punishment. This Essay proposes to serve the claimed needs of the crime victim by giving her control over the execution of ro percent of the convict's prison sentence. Although fraught with potential complications that would need to be addressed, if carefully managed, these victim control rights could serve the interests of victims, convicts, and society by enhancing psychological healing while reducing recidivism rates. At a minimum, however, victims could be made better off without jeopardizing the legitimate interests of either criminal defendants or society. The proposal seems worth at least a carefully constructed experiment.

\section{Notes}

Kenworthey Bilz, Donald Hall, Owen Jones, Nancy King, and Richard Nagareda have provided helpful comments regarding the ideas expressed in this Essay.

1 Jennifer Gerarda Brown, The Use of Mediation to Resolve Criminal Cases: A Procedural Critique, 43 EMORY L.J. 1247, 1254 (1994).

2 See id.; Lynne N. Henderson, The Wrongs of Victims' Rights, 37 StAN. L. REv. 937, 938.39 (1985) (discussing use of "blood feuds" and "outlawry" by victims, their families, and their communities after the collapse of the Roman Empire).

3 I do not mean to suggest that poor and wealthy victims are treated equally well in the criminal justice system. Even today the poor, the elderly, women, children, and racial minorities are more likely to be victimized than are others. See Kent Roach, Four Models of the Criminal Process, 89 J. CRIM. L. \& Criminology 671, 696, 698 (1999); Randall KenNedy, RaCE, CRIME AND THE LAW 76 (1997). Despite this very unfortunate disparity, the expenditure of state resources in the criminal justice system presumably enables the prosecution of greater numbers of crimes committed against poor individuals than was the case when crimes had to be privately prosecuted.

4 Approximately 95 percent of criminal convictions result from pleas of guilty or nolo contendere rather than from criminal trials. U.S. Dept. of Justice Bureau of Justice Statistics, Felony Sentences in State Courts, 1998, at 8.9 (2001).

5 See Paul G. Cassell, Barbarians at the Gates? A Reply to the Critics of the Victims' Rights Amendment, 1999 UTAH L. REV. $479,535$.

6 I have made this argument elsewhere. Erin Ann O'Hara, Victim Participation in the Criminal Process, 13 J. L. \& PoL'Y 229, 239.47 (2005).

7 See Hearing on H.J. Res. 64 Before the Subcomm. on the Constitution of the House Comm. on the Judiciary, 106th Cong. 45 (2000) (statement of Hon. Robert C. Scott, Congressional Representative from Virginia) ("[T] he polls demonstrate the power that victims have in $60,70,80,90$ percent passage of constitutional amendments. Whether they diminish the rights of defendants or not, they are very popular. The victims have the political power.").

8 See Robert Elias, Which Victim Movement? The Politics of Victim Policy, in Victims of Crime: Problems, Policies and Programs 229.47 (Arthur J. Lurigio et al. eds., 1990); Lynne Henderson, Co-Opting Compassion: The Federal Victims' Rights Amendment, 10 St. Thomas L. Rev. 579 (1998).

9 John W. Gillis \& Douglas E. Beloof, The Next Step for a Maturing Victim Rights Movement: Enforcing Crime Victim Rights in the Courts, 33 McGeorge L. Rev. 689, 690 (2002).

10 Douglas E. Beloof, The Third Wave of Victims' Rights: Standing, Remedy and Review, 2005 B.Y.U. L. REv. 255, 257, 265.68.

1118 U.S.C. $\S 3771$.

12 See, e.g., Henderson, supra note 2, at 982.86 (describing attempts to abolish the Fourth Amendment's exclusionary rule as part of victims' rights measures).

13 Beloof, supra note 10.

14 In 1990, 150 programs provided victim-offender mediation services. By 2000 , that number had grown to more than 1200 worldwide. Statement of Victim Offender Mediation Association, available at http://www.voma.org/abtvom.shtml.

15 For a discussion of the uses of VOM, see Mark William Bakker, Repairing the Breach and Reconciling the Discordant: Mediation in the Criminal Justice System, 72 N.C. L. Rev. 1479, 1482 (1994).

16 Mark S. Umbreit et al., The Impact of Victim-Offender Media tion: Two Decades of Research, 65 Fed. Probation 29 (2001).

17 Stephanos Bibas \& Richard A. Bierschbach, Integrating Remorse and Apology into Criminal Procedure, 114 YALE L.J. 85,132 (2004) (discussing studies).

18 Id. at $132 \cdot 33$ (discussing studies).

19 Victims frequently report that restitution was the primary reason they were interested in participating in VOM. Umbreit et al., supra note 16 , at 31 .

20 In post-mediation surveys, more than 75 percent of victims stated that they thought it important to receive an apology. Approximately 90 percent of offenders reported that media. tion was important as a vehicle to apologize to the victim. Umbreit, supra note 16 , at 72.73 .

21 Jonathan R. Cohen, Advising Clients to Apologize, 72 S. CAL. L. Rev. 1004 (1999); Aviva Orenstein, Apology Excepted: Incorporating a Feminist Analysis into Evidence Policy Where You Would Least Expect It, 28 Sw. U. L. Rev. 221 (1999).

22 See, e.g., Nathalie Des Rosiers et al., Legal Compensation for Sexual Violence: Therapeutic Consequences and Consequences for the Judicial System, 4 Psychol. PuB. PoL'Y \& L. 433 (1998) (desire for apology part of motivation of sexual assault vic. tims who file suit); RANDALL P. BEzANSOM ET AL., LIBEL LAW AND 
the Press: Mrth and Reality 79.94, 159.68, 172, 228.33 (1987) (libel victims often sue after defendants rebuff their requests for apology).

23 Jennifer K. Robbennolt, Apologies and Legal Settlement: An Empirical Investigation, $102 \mathrm{MicH}$. L. Rev. 460 (2003).

24 Erin Ann O'Hara \& Douglas Yarn, On Apology and Consilience, 77 WASH. U. L. REV. 1121 (2002).

25 David M. Lerman, Forgiveness in the Criminal Justice System, 27 FORDHAM URB. L.J. 1663, 1670 (2000)

26 Mark S. Umbreit, The Handbook of Victim-Offender Mediation 189 (2001).

27 See Stephen P. Garver, Restorative Justice, Punishment, and Atonement, 2003 UtaH L. Rev. 303, 315 \& n.42 (noting possible, though as yet unproven, health benefits from forgiveness); Frans B.M. de Waal, Evolutionary Ethics, Aggression, and Violence: Lessons from Primate Research, 32 J.L. MED. \& ETHICS 18 (2004) (noting that some studies indicate that forgiveness produces health benefits).

28 Stephanos Bibas, Plea Bargaining Outside the Shadow of Trial, 117 HARV. L. REv. 2463, 2543 (2004).

29 O'Hara \& Yarn, supra note 23 (noting that apologies, to be effective, often must provide at least an implicit promise to refrain from the same harmful conduct in the future).

30 Bibas \& Bierschbach, supra note 17.

31 Id. at 128.30

32 ld. at 140.41

33 ld. at 141.45 .
34 Brown, supra note 1 , at 1273.81 ; see also O'Hara \& Yarn, supra note 23 (noting that optimal time between transgres. sion and apology might well turn on severity of offense).

35 Linda G. Mills, The Justice of Recovery: How the State Can Heal the Violence of Crime, 57 Hastings L.J. 457 (2006) (dis. cussing improved healing that comes from active participation in VOM or other proceedings designed to address the aftermath of crime).

36 See HENDERSON, supra note 2 (discussing problem).

37 Susan Jacoby, Wild Justice: The Evolution of Revenge (1983) (discussing and critiquing social desire to cleanse victims from their tastes for revenge).

38 Of course, the federal system has abolished parole. Several states have likewise abolished parole. See Kevin R. Reitz, The New Sentencing Conundrum: Policy and Constitutional Law at Cross-Purposes?, 105 Colum. L. Rev. 1082, 1104 (2005) (providing figure listing states that have either abolished or limited the availability of parole).

39 Compare Johnson v. Rodriguez, 110 F.3d 299 (5th Cir. 1997) (convict has no constitutionally protected interest in use of victim's statements at parole proceeding), and Phillips v. Brennan, 969 F.2d 384 (7th Cir. 1992) (defendant has no con. stitutional right to receive notice of the contents of a victim's oral statement at parole proceeding), with Pardo v. Peters, 922 F.3d 843 (7th Cir. 1991) (inmate's due process rights would be violated if the parole board based its decision on information not disclosed to the inmate before the hearing). 